\title{
Synthesis and catalytic cracking performance of Fe/Ti-ZSM-5 zeolite from attapulgite mineral
}

\author{
Xiaozhao Zhou a, Yan Liu a, Xiangju Meng a, Baojian Shen b, Feng-Shou Xiao a,* \\ a Department of Chemistry, Zhejiang University, Hangzhou 310028, Zhejiang, China \\ b Faculty of Chemical Engineering, China University of Petroleum, Beijing 102249, China
}

A R T I C L E I N F O

Article history:

Received 30 December 2012

Accepted 28 April 2013

Published 20 August 2013

\section{Keywords:}

Natural attapulgite

Iron

Titanium

ZSM-5 zeolite

Catalytic cracking

Light olefins

Propylene

\begin{abstract}
A B S T R A C T
Fe/Ti-ZSM-5 zeolite was synthesized successfully from treated attapulgite (ATP). This mineral consists of amorphous silica containing Fe and Ti species. X-ray diffraction patterns, scanning electron microscopy images, and nitrogen sorption isotherms indicate that the sample has a typical MFI structure, high crystallinity, and large specific surface area. Temperature-programmed desorption of ammonia and $\mathrm{H}_{2}$ temperature-programmed reduction indicates that the Fe/Ti-ZSM-5 zeolite is strongly acidic and has superior redox properties. More importantly, compared with conventional ZSM-5 zeolite, Fe/Ti-ZSM- 5 performs well, resulting in an increase in yield of $0.21 \%$ propylene and $0.33 \%$ total light olefins in the catalytic cracking of Canadian LGO (light gas oil). These results suggest that the presence of $\mathrm{Fe}$ and $\mathrm{Ti}$ species in ZSM-5 zeolite is favorable for enhancing light olefin yields, which is potentially important for oil refining in the future.
\end{abstract}

(C) 2013, Dalian Institute of Chemical Physics, Chinese Academy of Sciences. Published by Elsevier B.V. All rights reserved.

\section{Introduction}

Propylene production has attracted much attention because propylene is an important industrial chemical. Currently, most propylene is derived from steam crackers and refinery fluid catalytic cracking (FCC) units [1-4]. Naphtha is the main raw material in the steam crackers for propylene production, but its limited supply constrains this cracking process. The amount of propylene produced by the FCC process has increased with time because of advantages in the high ratio of propylene to ethylene and the low cost of investment and production of the FCC process [5,6]. ZSM-5 zeolite with three-dimensional medium pore sizes (10-membered rings), excellent thermal and hydrothermal stability, and low activity for hydrogen transfer is one of the most important additives in the FCC process for enhancing propylene yield [7-9].

The introduction of transition elements in ZSM-5 zeolites results in the formation of highly efficient FCC catalyst additives [10-14]. For example, Lu et al. [15,16] reported that Fe and $\mathrm{Cr}$ et al. in ZSM-5 zeolite could improve propylene and ethylene yields in the catalytic cracking of isobutene. Maia et al. $[17,18]$ reported that the introduction of Ni in ZSM-5 by impregnation and ion-exchange methods enhanced the light olefin yield effectively. Li and Hao et al. $[19,20]$ reported that the impregnation of Fe and Ti into ZSM-5 zeolite was favorable for increasing propylene and ethylene yields. However, the introduction of transition elements into ZSM-5 in these conventional ways is often complex and pure chemicals are required. Therefore, it is desirable to prepare ZSM-5 zeolites that contain transition elements from low-cost raw materials. One-pot synthesis

\footnotetext{
* Corresponding author. Tel: +86-571-88273698; E-mail: fsxiao@zju.edu.cn This work was supported by the National Natural Science Foundation of China (U1162201). DOI: 10.1016/S1872-2067(12)60638-X | http://www.sciencedirect.com/science/journal/18722067 | Chin. J. Catal.,Vol. 34,No. 8, August 2013
} 
of low-cost ZSM-5 zeolite is possible using transition elements derived from natural attapulgite (ATP).

ATP, a well-known natural mineral, is a crystalline-hydrated magnesium and aluminum silicate with composition $\left(\mathrm{OH}_{2}\right)_{4}(\mathrm{OH})_{2} \mathrm{M}_{6} \mathrm{Si}_{8} \mathrm{O}_{20} \cdot 4 \mathrm{H}_{2} \mathrm{O}(\mathrm{M}=\mathrm{Al}, \mathrm{Mg}, \mathrm{Fe})$, having a unique chain structure, high surface area, and fibrous morphology [21-26]. It has been used in catalyst supports, nanocomposites, and environmental absorbents [27-30]. The amorphous silica in ATP containing only $\mathrm{Al}, \mathrm{Fe}$, and Ti metal species can be obtained by acid treatment and offers an ideal raw material for Fe/Ti-ZSM-5 zeolite synthesis.

In this work, we present a route for synthesizing the Fe/Ti-ZSM-5 additive in FCC catalysts using treated ATP as silica and Fe, and Ti reagents by a one-pot method. The catalytic tests show that Fe/Ti-ZSM-5 exhibits a relatively high yield of propylene and ethylene in the catalytic cracking of Canadian light gas oil (LGO) compared with conventional ZSM-5 zeolite.

\section{Experimental}

\subsection{Preparation of Fe/Ti-ZSM-5}

ATP obtained from Xuyi, China had a typical $\mathrm{SiO}_{2} / \mathrm{MgO} /$ $\mathrm{Al}_{2} \mathrm{O}_{3} / \mathrm{Fe}_{2} \mathrm{O}_{3} / \mathrm{CaO} / \mathrm{K}_{2} \mathrm{O} / \mathrm{Na}_{2} \mathrm{O} / \mathrm{TiO}_{2} / \mathrm{H}_{2} \mathrm{O}$ composition (wt\%) of 59.83/14.49/8.35/4.20/0.79/0.77/0.22/1.10/10.15. All chemicals were from Shanghai Chemical Reagent Co. and were used as received without purification.

Before zeolite synthesis, ATP was pretreated with $37 \% \mathrm{HCl}$ solution. As a typical process, $2.0 \mathrm{~g}$ of ATP, $2.7 \mathrm{~g}$ of concentrated $\mathrm{HCl}$ and $17 \mathrm{ml}$ of water were added to a Teflon-lined autoclave, followed by heating at $180{ }^{\circ} \mathrm{C}$ for $14 \mathrm{~h}$. The product was filtered and washed with deionized water until no $\mathrm{Cl}^{-}$was detected and then dried at $120^{\circ} \mathrm{C}$ for $4 \mathrm{~h}$.

For the typical synthesis of Fe/Ti-ZSM-5 zeolite, $0.09 \mathrm{~g}$ of $\mathrm{NaAlO}_{2}$ (AR) and $4.5 \mathrm{~g}$ of tetrapropylammonium hydroxide (TPAOH, $19.6 \mathrm{wt} \%$ ) were dissolved in $15 \mathrm{ml}$ of water, followed by the addition of $1.5 \mathrm{~g}$ of acid-treated ATP. After stirring for 4 $\mathrm{h}$, a gel was obtained and transferred into a Teflon-lined autoclave. After crystallization at $180{ }^{\circ} \mathrm{C}$ for $12 \mathrm{~h}$, the product with MFI zeolite structure was obtained by filtering, washing with deionized water, and drying at $100{ }^{\circ} \mathrm{C}$ for $4 \mathrm{~h}$. The sample was calcined at $550{ }^{\circ} \mathrm{C}$ for $5 \mathrm{~h}$ to remove the organic templates and was designated Fe/Ti-ZSM-5.

Conventional ZSM- 5 was synthesized under the same conditions as Fe/Ti-ZSM-5 using equal silica (91.8 wt\%) to replace the treated ATP. The product was designated ZSM-5-C.

As a typical procedure for the ion-exchange of sodium with ammonium, $1.0 \mathrm{~g}$ of zeolite was added into $50 \mathrm{ml}$ of ammonium nitrate (AR) solution ( $1 \mathrm{~mol} / \mathrm{L})$ at $80{ }^{\circ} \mathrm{C}$ and stirred for $12 \mathrm{~h}$. This process was repeated twice. H-form zeolites were obtained by calcination of the ion-exchanged $\mathrm{NH}_{4}$-form zeolites at $500{ }^{\circ} \mathrm{C}$ for $4 \mathrm{~h}$.

\subsection{Characterization}

Sample composition was determined by inductively coupled plasma (ICP) with a Perkin-Elmer plasma 40 emission spec- trometer. Scanning electron microscopy (SEM) experiments were performed on a Hitachi SU-1510 electron microscope. $\mathrm{X}$-ray powder diffraction (XRD) patterns were measured with a Rigaku Ultimate VI X-ray diffractometer (40 kV, $40 \mathrm{~mA})$ using $\mathrm{Cu} K_{\alpha}(\lambda=0.15406 \mathrm{~nm})$ radiation. The catalyst acidity was measured by the temperature-programmed desorption of ammonia ( $\mathrm{NH}_{3}$-TPD). The catalyst $(0.1 \mathrm{~g})$ was pretreated at 400-650 ${ }^{\circ} \mathrm{C}$ in $\mathrm{N}_{2}$ flow for $1 \mathrm{~h}$, followed by the adsorption of $\mathrm{NH}_{3}$ at $100{ }^{\circ} \mathrm{C}$ for $0.5 \mathrm{~h}$. After saturation, the catalyst was purged by $\mathrm{N}_{2}$ flow for $0.5 \mathrm{~h}$ to remove the physically adsorbed ammonia on the sample. $\mathrm{NH}_{3}$ desorption was carried out from 100 to $700{ }^{\circ} \mathrm{C}$ with a heating rate of $10^{\circ} \mathrm{C} / \mathrm{min}$. The amount of $\mathrm{NH}_{3}$ desorbed from the sample was obtained by comparing the area under the curve with a sample containing a known amount of $\mathrm{NH}_{3}$ using a thermal conductivity detector. Temperature-programmed reduction of $\mathrm{H}_{2}\left(\mathrm{H}_{2}\right.$-TPR) analysis was performed with a TPDT01100Series from Thermo Electron Corporation. The $\mathrm{N}_{2}$ sorption isotherms at the liquid nitrogen temperature were measured using a Micromeritics ASAP 2010M and Tristar system. UV-visible spectra were measured using a Shimadzu UV-3100.

\subsection{Catalytic tests of LGO}

As a typical procedure for LGO catalyst preparation, the catalyst additive (35 wt\% ZSM-5, $50 \mathrm{wt} \%$ kaolin and $15 \mathrm{wt} \%$ alumina binder) was shaped by spray-drying. Then, $10 \mathrm{wt} \%$ catalyst additive and $90 \mathrm{wt} \%$ USY were mixed to form the LGO catalyst. The LGO catalyst containing Fe/Ti-ZSM-5 or ZSM-5-C was denoted $\mathrm{C}_{\mathrm{Fe}}$ /Ti-ZSM-5 or CZSM-5-C. Before reaction, the catalyst was treated at $800{ }^{\circ} \mathrm{C}$ for $4 \mathrm{~h}$ under $100 \%$ steaming. The catalyst size distribution was $38-212 \mu \mathrm{m}$.

Catalytic cracking data were obtained on an advanced catalyst evaluation bench unit (ACE, Kayser Corp) with FCC unit reaction conditions as follows: reaction temperature at $530{ }^{\circ} \mathrm{C}$, catalyst to oil mass ratio of 6.0 , contact time $90 \mathrm{~s}$, and catalyst of $9.0 \mathrm{~g}$. The products were detected by an online GC-MS with instrumental error of $0.01 \%$. The feedstock LGO was derived from Canada oil sand, as listed in Table 1.

\section{Results and discussion}

\subsection{Characterization results of ATP}

Figure 1 shows XRD patterns of as-received and ac-

Table 1

Properties of feedstock Canadian light gas oil (LGO).

\begin{tabular}{lc}
\hline Item & LGO \\
\hline Density $\left(20^{\circ} \mathrm{C}, \mathrm{g} / \mathrm{cm}^{3}\right)$ & 0.8726 \\
Viscosity $\left(40^{\circ} \mathrm{C}, \mathrm{Pa} \cdot \mathrm{s}\right)$ & 4.71 \\
Carbon residue $(\mathrm{wt} \%)$ & 0.008 \\
Average molecular weight $(\mathrm{g} / \mathrm{mol})$ & 230 \\
$\mathrm{H}(\mathrm{wt} \%)$ & 12.86 \\
$\mathrm{C}(\mathrm{wt} \%)$ & 87.11 \\
$\mathrm{H} / \mathrm{C}$ & 1.77 \\
Saturated carbons $(\mathrm{wt} \%)$ & 69.9 \\
Aromatics $(\mathrm{wt} \%)$ & 30.1 \\
Resins and asphaltenes (wt $\%)$ & 0 \\
\hline
\end{tabular}




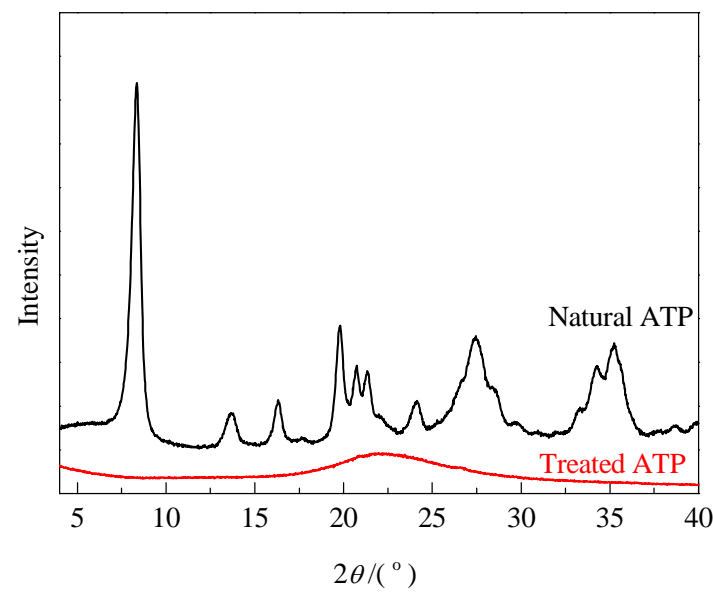

Fig. 1. XRD patterns of natural and acid-treated ATP.

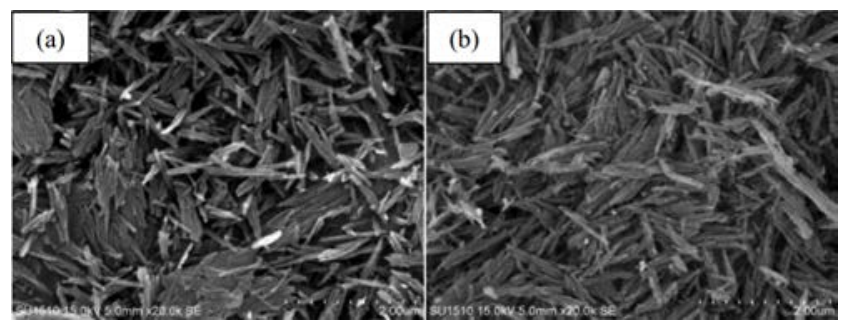

Fig. 2. SEM images of natural (a) and acid-treated (b) ATP.

id-treated ATP. Before acid treatment, ATP exhibits a typical crystalline structure $\left(8.35^{\circ}, 13.68^{\circ}, 16.31^{\circ}, 19.80^{\circ}, 20.73^{\circ}\right.$, $21.34^{\circ}, 24.11^{\circ}, 27.47^{\circ}, 34.25^{\circ}$, and $35.24^{\circ}$ ). After acid treatment, the sample contains an amorphous phase, indicating that the crystalline structure is destroyed.

Figure 2 shows SEM images of the as-received and acid-treated ATP. Both samples exhibit similar fiber morphology with approximately 30-50 $\mathrm{nm}$ in diameter and 1-2 $\mu \mathrm{m}$ in length.

Table 2 presents the chemical composition of ATPs. Natural ATP contains $\mathrm{SiO}_{2}$ (59.83\%), $\mathrm{MgO}$ (14.49\%), $\mathrm{Al}_{2} \mathrm{O}_{3}$ (8.35\%), $\mathrm{Fe}_{2} \mathrm{O}_{3}(4.2 \%)$, and traces of $\mathrm{Na}, \mathrm{K}, \mathrm{Ca}, \mathrm{Mn}$, and $\mathrm{Ti}$ species. The metal cations are located between unique chains. After acid treatment, most of the metal cations in the ATP are removed, with resulting chemical composition of $\mathrm{SiO}_{2}$ (96.4\%), $\mathrm{Al}_{2} \mathrm{O}_{3}$ $(0.8 \%), \mathrm{Fe}_{2} \mathrm{O}_{3}(1.3 \%)$, and $\mathrm{TiO}_{2}(1.5 \%)$. These results suggest that the acid treatment does not influence the sample morphology but changes the sample elemental composition significantly.

\subsection{Characterization results of Fe/Ti-ZSM-5}

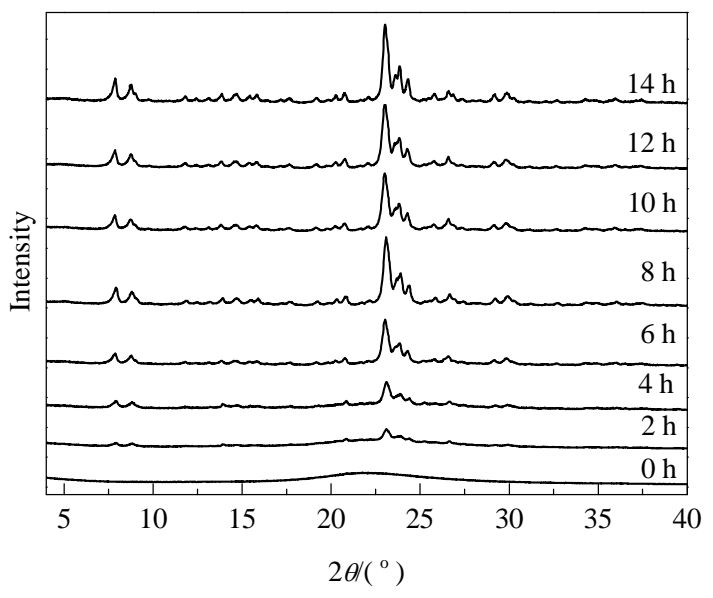

Fig. 3. XRD patterns of Fe/Ti-ZSM-5 synthesized at different crystallization times.

Figure 3 shows XRD patterns of Fe/Ti-ZSM-5 crystallized at various times. Before crystallization, the sample is amorphous. At $2 \mathrm{~h}$ crystallization time, a series of weak peaks appear in the XRD pattern associated with the MFI structure. With increasing crystallization time from 4 to $10 \mathrm{~h}$, the XRD peaks at $23.03^{\circ}$, $23.83^{\circ}$, and $24.28^{\circ}$ associated with the fast crystallization of Fe/Ti-ZSM-5 are enhanced significantly. For a crystallization time greater than $12 \mathrm{~h}$, the Fe/Ti-ZSM- 5 crystallinity changes little, suggesting complete crystallization of the sample.

Figure 4 show SEM images of the Fe/Ti-ZSM-5 crystallized at various times. Samples in the starting gel retain their nano-fiber morphology as natural ATP (Fig. 4(a)). Small crystal particles $(0.5-1 \mu \mathrm{m})$ appear in the products as the crystallization time reaches $2 \mathrm{~h}$. These small particles increase in size $(1.5-2.0 \mu \mathrm{m})$ as the crystallization time is prolonged to $6 \mathrm{~h}$. Finally, the crystal particles are distributed mainly around 2.0 $\mu \mathrm{m}$ in diameter with full disappearance of the nano-fiber morphology at a crystallization time of $14 \mathrm{~h}$. Figure 4(i) and (j) show SEM images of the ZSM-5-C synthesized from silica. ZSM-5-C has smaller crystal particles than Fe/Ti-ZSM-5.

Table 2 presents the composition of Fe/Ti-ZSM-5 and ZSM-5-C. Both have a similar Si/Al ratio of 14.4 and 13.2.

Figure 5 shows the $\mathrm{N}_{2}$ sorption isotherms of the ZSM- 5 samples synthesized from the treated ATP (Fe/Ti-ZSM-5) and silica (ZSM-5-C). Both exhibit a steep increase in the curve at a relative pressure of $10^{-6}<p / p_{0}<0.01$. The textural parameters of Fe/Ti-ZSM-5 and ZSM-5-C are provided in Table 3. These data show that the textural parameters of Fe/Ti-ZSM-5 are consistent with ZSM-5-C synthesized by conventional methods. These results also confirm that it is possible to synthesize Fe/Ti-ZSM-5 from treated ATP by a one-pot method. Compared

Table 2

Chemical composition of ATP and zeolite samples.

\begin{tabular}{lccccccccc}
\hline \multirow{2}{*}{ Sample } & \multicolumn{9}{c}{ Composition (wt\%) } \\
\cline { 2 - 9 } & $\mathrm{SiO}_{2}$ & $\mathrm{MgO}$ & $\mathrm{Al}_{2} \mathrm{O}_{3}$ & $\mathrm{Fe}_{2} \mathrm{O}_{3}$ & $\mathrm{CaO}$ & $\mathrm{Na}_{2} \mathrm{O}+\mathrm{K}_{2} \mathrm{O}$ & $\mathrm{MnO}^{2}$ & $\mathrm{TiO}_{2}$ & $\mathrm{H}_{2} \mathrm{O}$ \\
\hline Natural ATP & 59.83 & 14.49 & 8.35 & 4.20 & 0.79 & 0.99 & 0.094 & 1.1 \\
Acid-treated ATP & 96.40 & - & 0.8 & 1.3 & - & - & - & 1.15 \\
Fe/Ti-ZSM-5 & 93.07 & - & 5.46 & 0.58 & - & - & - & 0.88 \\
ZSM-5-C & 93.93 & - & 6.07 & - & - & - & - & - & - \\
\hline
\end{tabular}



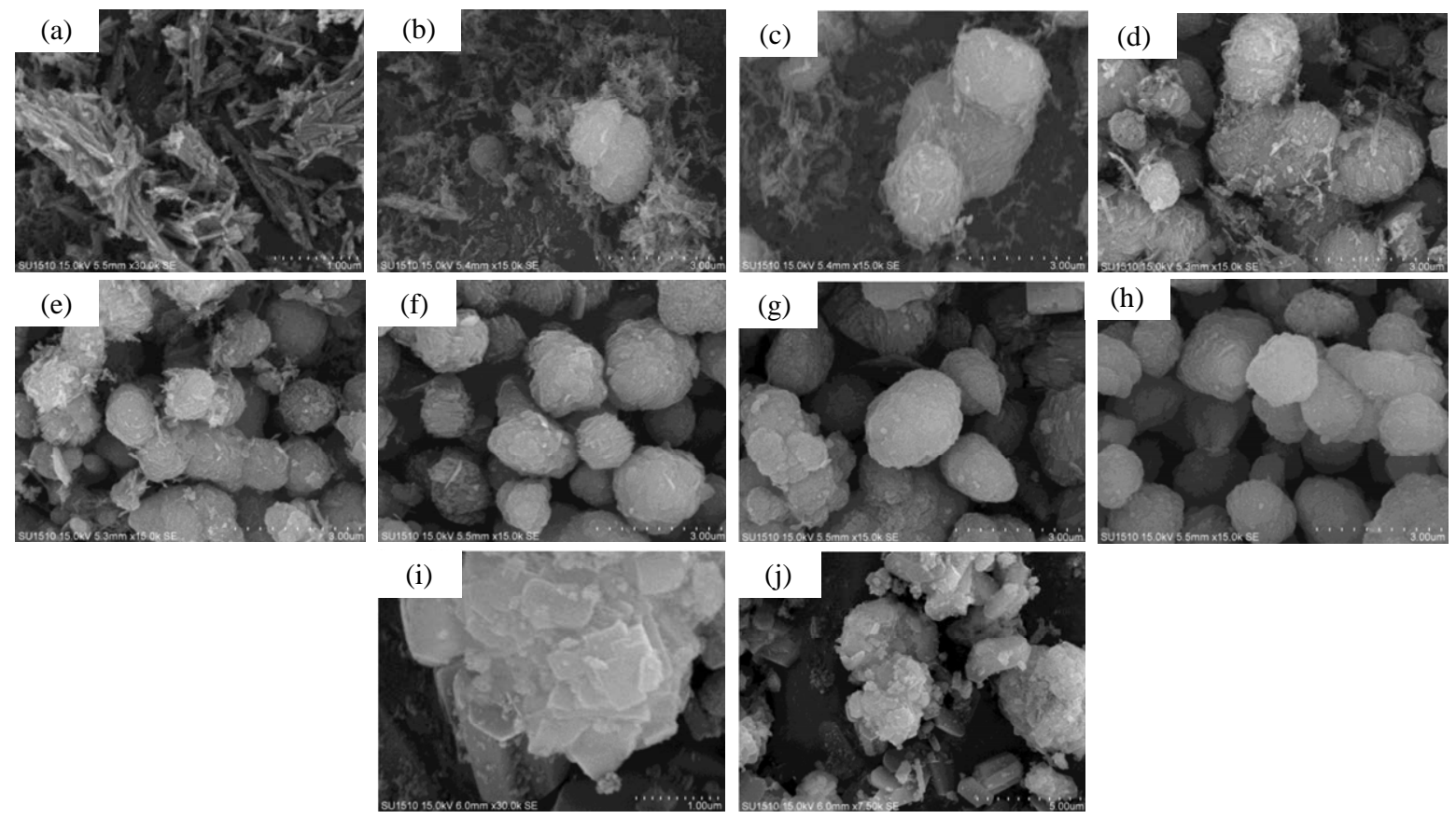

Fig. 4. SEM images of Fe/Ti-ZSM-5 (a-h) and ZSM-5-C (i, j) synthesized at different crystallization time. (a) 0 h; (b) 2 h; (c) 4 h; (d) 6 h; (e) 8 h; (f) 10 h; (g, i, j) 12; (h) $14 \mathrm{~h}$.

with ZSM-5-C, Fe/Ti-ZSM-5 has similar Si/Al ratios, surface area, and pore volume. The difference between them is that Fe/Ti-ZSM-5 contains little Fe and Ti.

To the best of our knowledge, although various zeolites have been synthesized from various natural minerals [32-34], no report exists on the synthesis of high silica zeolite using ATP except for the synthesis of alumina-rich zeolite A [35]. There-

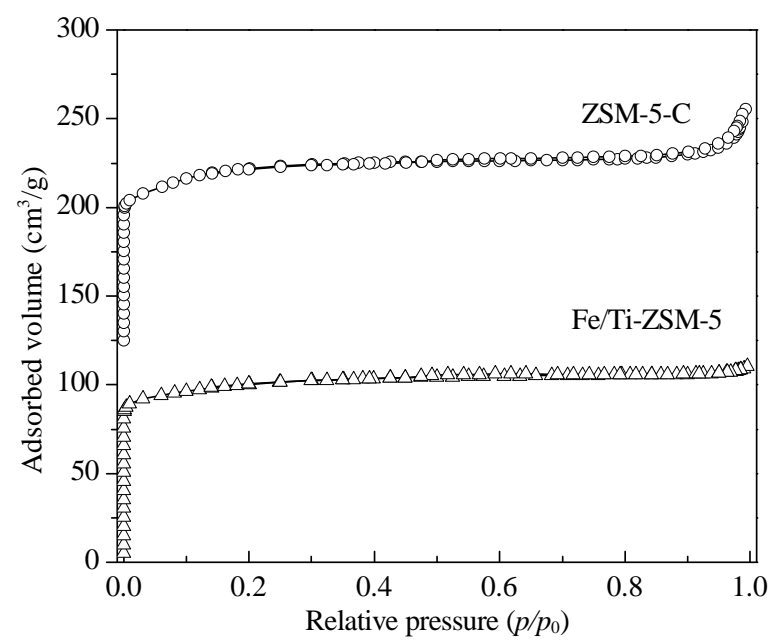

Fig. 5. $\mathrm{N}_{2}$ sorption isotherms of ZSM-5. Isotherms for sample ZSM-5-C offset vertically by $120 \mathrm{~cm}^{3} / \mathrm{g}$.

Table 3

Textural parameters of ZSM-5 samples.

\begin{tabular}{lccccc}
\hline Sample & $\begin{array}{c}A_{\text {BET }} \\
\left(\mathrm{m}^{2} / \mathrm{g}\right)\end{array}$ & $\begin{array}{c}A_{\text {micro }} \\
\left(\mathrm{m}^{2} / \mathrm{g}\right)\end{array}$ & $\begin{array}{c}A_{\text {ext }} \\
\left(\mathrm{m}^{2} / \mathrm{g}\right)\end{array}$ & $\begin{array}{c}V_{\text {total }} \\
\left(\mathrm{cm}^{3} / \mathrm{g}\right)\end{array}$ & $\begin{array}{c}V_{\text {micro }} \\
\left(\mathrm{cm}^{3} / \mathrm{g}\right)\end{array}$ \\
\hline Fe/Ti-ZSM-5 & 339 & 260 & 79 & 0.17 & 0.12 \\
ZSM-5-C & 350 & 227 & 123 & 0.18 & 0.10 \\
\hline
\end{tabular}

fore, the one-pot synthesis of Fe/Ti-ZSM-5 using ATP as feedstock could be important for industrial applications in the future.

Figure 6 shows the UV-Vis spectra of natural ATP, acid-treated ATP, and Fe/Ti-ZSM-5 samples. The natural ATP has an absorption peak at $250 \mathrm{~nm}$, probably because of the mutual interference of polyatomic species ( $\mathrm{Mg}, \mathrm{Al}, \mathrm{Fe}, \mathrm{Mn}$, and $\mathrm{Ti}$ ). After acid treatment, the natural ATP loses most of its metal atoms, providing a low absorption peak around $250 \mathrm{~nm}$. Significantly, there are two strong absorption peaks at 212 and 240 $\mathrm{nm}$ for Fe/Ti-ZSM-5. Generally, the peak at $212 \mathrm{~nm}$ is related to the electronic transitions of four-coordinated Ti species, while the peak at $240 \mathrm{~nm}$ is associated with electronic transitions of four-coordinated Fe species in the sample. The small peak around $325 \mathrm{~nm}$ is related to the existence of $\mathrm{TiO}_{2}$ crystals in the

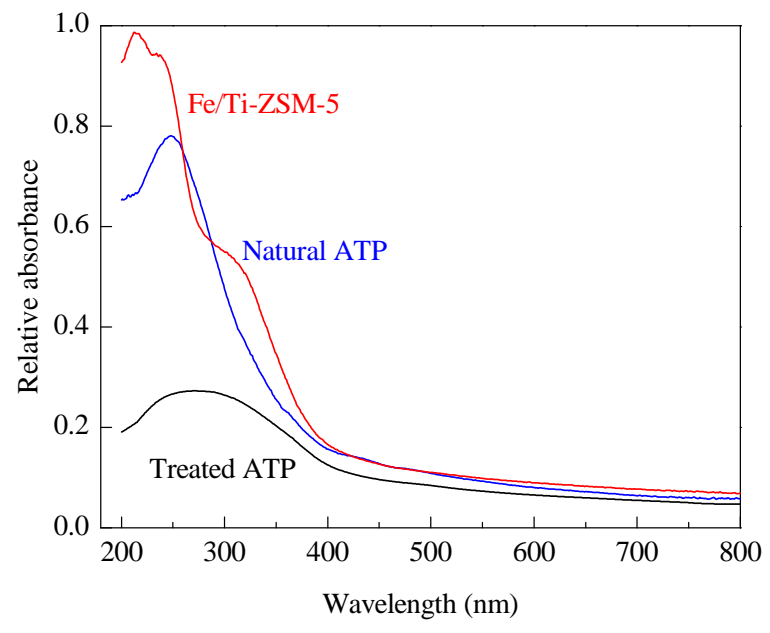

Fig. 6. UV-Vis spectra of various samples. 


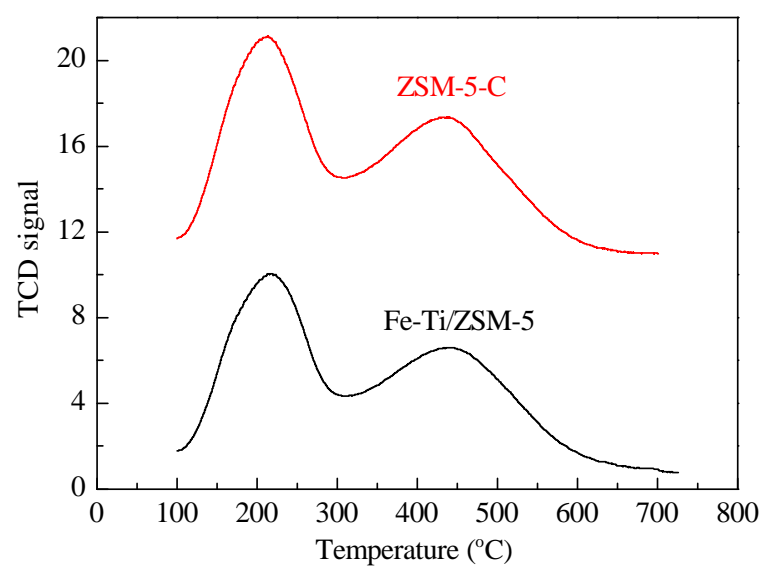

Fig. 7. $\mathrm{NH}_{3}$-TPD profiles of Fe/Ti-ZSM-5 and ZSM-5-C samples. Curve for sample ZSM-5-C offset vertically by 10 .

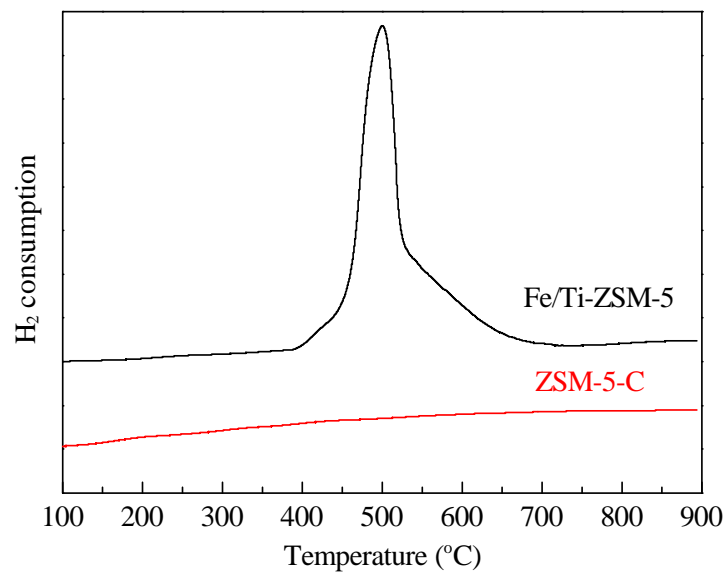

Fig. 8. $\mathrm{H}_{2}$-TPR profiles of Fe/Ti-ZSM-5 and ZSM-5-C samples.

sample.

Figure 7 shows the $\mathrm{NH}_{3}$-TPD profiles of Fe/Ti-ZSM-5 and ZSM-5-C samples. Generally, the desorption temperatures centered around 200 and $400{ }^{\circ} \mathrm{C}$ are related to the weak and strong acid sites respectively, while the desorption peak area represents the acid amount in the $\mathrm{NH}_{3}$-TPD test [36]. In this work, both samples show similar desorption peaks at 218 and $440{ }^{\circ} \mathrm{C}$. However, ZSM-5-C has a slightly higher acid amount than the Fe/Ti-ZSM-5 because of its small difference in $\mathrm{Si} / \mathrm{Al}$ ratio.

Figure 8 shows the $\mathrm{H}_{2}$-TPR profiles of Fe/Ti-ZSM-5 and ZSM-5-C samples. Normally, the Fe species on ZSM-5 result in peaks at 350 and $420^{\circ} \mathrm{C}$ associated with the reduction of $\mathrm{Fe}^{3+}$ to $\mathrm{Fe}^{2+}$ and $\mathrm{Fe}^{2+}$ to $\mathrm{Fe}^{0}$ respectively, while Ti species on ZSM-5 yield a peak at $670{ }^{\circ} \mathrm{C}$ associated with the reduction of $\mathrm{TiO}_{2}$ $[19,20]$. Interestingly, Fe/Ti-ZSM- 5 shows a unique peak range from 400 to $700{ }^{\circ} \mathrm{C}$, which may result from the difficulty in the reduction of $\mathrm{Fe}$ species in the framework and the interaction between $\mathrm{TiO}_{2}$ with surface hydroxyl groups in the sample.

\subsection{Catalytic performance}

Table 4 presents the product distribution in catalytic cracking of Canadian LGO over catalysts containing Fe/Ti-ZSM-5 and
Table 4

Product distribution in catalytic cracking of Canadian LGO over CzSM-5-C and $\mathrm{C}_{\mathrm{Fe} / \mathrm{Ti}-\mathrm{ZSM}-5}$ catalysts.

\begin{tabular}{lcc}
\hline Catalyst additive & ZSM-5-C & Fe/Ti-ZSM-5 \\
\hline Product distribution (wt\%) & & \\
$\quad$ Dry gas & 1.84 & 1.88 \\
LPG & 19.85 & 20.12 \\
Gasoline & 42.43 & 42.85 \\
LCO & 29.71 & 28.60 \\
Bottoms & 5.04 & 5.46 \\
Coke & 1.12 & 1.10 \\
Liquid yield (\%) & 92.01 & 91.56 \\
Ethylene yield (\%) & 0.91 & 0.94 \\
Propylene yield (\%) & 5.98 & 6.16 \\
$\mathrm{C}_{2}=+\mathrm{C}_{3}=+\mathrm{C}_{4}=$ yield (\%) & 12.66 & 12.99 \\
\hline
\end{tabular}

ZSM-5-C additives. When ZSM-5-C was used as a catalyst additive, the CZSM-5-C catalyst yielded $5.98 \%$ propylene and $12.66 \%$ total light olefins. When Fe/Ti-ZSM-5 was used as catalyst additive, the $\mathrm{C}_{\mathrm{Fe} / \mathrm{Ti}-\mathrm{ZSM}-5}$ catalyst yielded $6.16 \%$ propylene and $12.99 \%$ total light olefins. Considering that ZSM-5-C has a larger BET surface area and more abundant acid sites than the $\mathrm{Fe} / \mathrm{Ti}-\mathrm{ZSM}-5$, higher yields of light olefins over the $\mathrm{C}_{\mathrm{Fe} / \mathrm{Ti}-\mathrm{ZSM}-5}$ catalyst than those over the CzSM-5-c catalyst should be related to the contribution of Fe and Ti species in the Fe/Ti-ZSM-5. It is possible that the Fe and Ti species in the catalyst improve the catalytic redox property, which is helpful for $\beta$-scission to produce light olefins. This result is in good agreement with the reported literature [11,18-20].

\section{Conclusions}

Fe/Ti-ZSM-5 was synthesized successfully from acid-treated ATP as silica and Fe, and Ti feedstock by the one-pot method. Compared with ZSM-5-C, Fe/Ti-ZSM-5 has a similar crystallinity, textural parameters, and acidity. The catalyst prepared from the Fe/Ti-ZSM-5 additive shows a higher yield of propylene and total light olefins in the LGO catalytic cracking test, which is related to its unique redox property. These features could be important for the production of propylene and light olefins in the FCC process in future.

\section{References}

[1] Wallenstein D, Kanz B, Haas A. Appl Catal A, 2000, 192: 105

[2] Corma A, Melo F V, Sauvanaud L, Ortega F. Catal Today, 2005, 107: 699

[3] den Hollander M A, Wissink M, Makkee M, Moulijn J A. Appl Catal A, 2002, 223: 85

[4] Wallenstein D, Harding R H. Appl Catal A, 2001, 214: 11

[5] Lei Y X. Petrol Petrochem Today (雷燕湘. 当代石油石化), 2007, 15(4): 38

[6] Zhou H Z. Chemical Techno-Economics (周宏中. 化工技术经济), 2004, 22(9): 28

[7] Degnan T F, Chitnis G K, Schipper P H. Microporous Mesoporous Mater, 2000, 35: 245

[8] Adewuyi Y G, Klocke D J, Buchanan J S. Appl Catal A, 1995, 131: 121

[9] Buchanan J S. Catal Today, 2000, 55: 207

[10] Aitani A, Yoshikawa T, Ino T. Catal Today, 2000, 60: 111 


\section{Graphical Abstract}

Chin. J. Catal., 2013, 34: 1504-1512 doi: 10.1016/S1872-2067(12)60638-X

\section{Synthesis and catalytic cracking performance of Fe/Ti-ZSM-5 zeolite from attapulgite mineral}

Xiaozhao Zhou, Yan Liu, Xiangju Meng, Baojian Shen, Feng-Shou Xiao*

Zhejiang University; China University of Petroleum

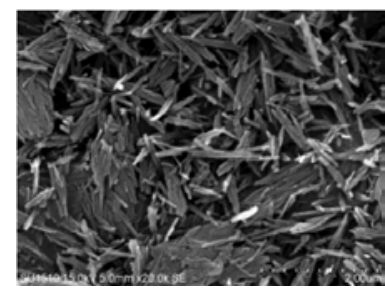

Attapulgite clay

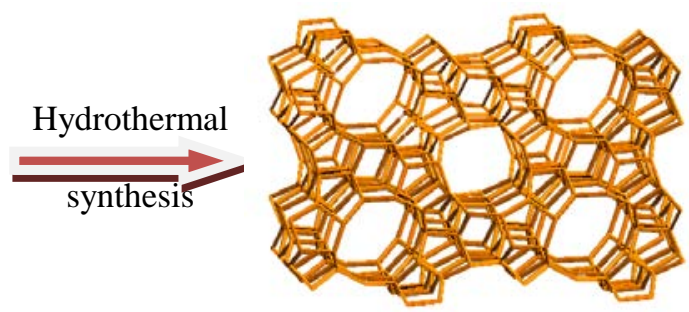

Fe/Ti-ZSM-5

Fe/Ti-ZSM-5 zeolite was synthesized from treated attapulgite (ATP) mineral. Compared with conventional ZSM-5 zeolite, Fe/Ti-ZSM-5 exhibits relatively high yields of light olefins in the catalytic cracking of Canadian light gas oil.

[11] Luo Y B, Ouyang Y, Shu X T, He M Y. Stud Surf Sci Catal, 2007, 170: 600

[12] Wang P, Shen B J, Shen D D, Peng T, Gao J S. Catal Commun, 2007, 8: 1452

[13] Komvokis V G, Iliopoulou E F, Vasalos I A, Triantafyllidis K S, Marshall C L. Appl Catal A, 2007, 325: 345

[14] Li X H, Li C Y, Zhang J F, Yang C H, Shan H H.J Nat Gas Chem, 2007, 16: 92

[15] Lu J Y, Zhao Z, Xu C M, Zhang P, Duan A J. Catal Commun, 2006, 7: 199

[16] Lu J Y, Zhao Z, Xu C M, Duan A J, Zhang P. Catal Lett, 2006, 109: 65

[17] Maia A J, Louis B, Lam Y L, Pereira M M. J Catal, 2010, 269: 103

[18] Maia A J, Oliveira B G, Esteves P M, Louis B, Lam Y L, Pereira M M. Appl Catal A, 2011, 403: 58

[19] Li X F, Shen B J, Xu C M. Appl Catal A, 2010, 375: 222

[20] Hao K, Shen B J, Wang Y D, Ren J. J Ind Eng Chem, 2012, 18: 1736

[21] Xu R R, Pang W Q, Yu J H, Huo Q S, Chen J S. Chemistry of Zeolite and Related Porous Materials. Singapore: Wiley, 2007. 152

[22] Newsam J M. Science, 1986, 231: 1093

[23] Cundy C S, Cox P A. Chem Rev, 2003, 103: 663

[24] Li Z F, Marler B, Gies H. Chem Mater, 2008, 20: 1896

[25] Gevert B, Eriksson L, Toerncrona A. J Porous Mater, 2011, 18: 723
[26] Gao X H, Qin Z X, Wang B J, Zhao X Z, Li J C, Zhao H J, Liu H H, Shen B J. Appl Catal A, 2012, 413: 254

[27] Murray H H. Appl Clay Sci, 2000, 17: 207

[28] Cao J L, Shao G S, Wang Y, Liu Y P, Yuan Z Y. Catal Commun, 2008, 9: 2555

[29] Liu Y S, Liu P, Su Z X, Li F S, Wen F S. Appl Surf Sci, 2008, 255: 2020

[30] Wang W B, Zheng Y, Wang A Q. Polym Adv Technol, 2008, 19: 1852

[31] Shi L M, Yao J F, Jiang J L, Zhang L X, Xu N P. Microporous Mesoporous Mater, 2009, 122: 294

[32] Purnomo C W, Salim C, Hinode H. Microporous Mesoporous Mater, 2012, 162: 6

[33] Kovo A S, Hernandez O, Holmes S M. J Mater Chem, 2009, 19: 6207

[34] Colina F G, Llorens J. Microporous Mesoporous Mater, 2007, 100: 302

[35] Jiang J L, Feng L D, Gu X, Qian Y H, Gu Y X, Duanmu C S. Appl Clay Sci, 2012, 55: 108

[36] Ren L M, Zhang Y B, Zeng S J, Zhu L F, Sun Q, Zhang H Y, Yang C G, Meng X J, Yang X G, Xiao F-S. Chin J Catal (任利敏, 张一波, 曾尚景, 朱龙凤, 孙琦, 张海燕, 杨承广, 孟祥举, 杨向光, 肖丰收. 催化学报), 2012, 33: 92

\author{
周晓兆, 刘艳 ${ }^{\mathrm{a}}$, 孟祥举 ${ }^{\mathrm{a}}$, 申宝剑 ${ }^{\mathrm{b}}$, 肖丰收 ${ }^{\mathrm{a}}{ }^{*}$ \\ a浙江大学化学系, 浙江杭州 310028 \\ ${ }^{\mathrm{b}}$ 中国石油大学(北京)化学工程学院, 北京 102249
}

以天然凹凸棒石为原料合成Fe/Ti-ZSM-5沸石分子篮及其催化裂化性能

摘要: 以天然凹凸棒石为硅源、铁源和钛源, 一步合成了 Fe/Ti-ZSM-5分子篮. X 射线衍射、扫描电镜和 $\mathrm{N}_{2}$ 吸附等温线测定结果表 明, 所合成的样品具有良好的结晶度和较大的比表面积; $\mathrm{NH}_{3}$ 程序升温脱附和 $\mathrm{H}_{2}$ 程序升温还原结果表明, 该样品具有强的酸性和 氧化还原性能. 更为重要的是, 与常规方法制备的ZSM-5沸石相比, Fe/Ti-ZSM-5在催化裂解原料油(LGO, 加拿大)的测试中, 丙烯 的产率提高 $0.21 \%$, 总轻烯烃的产率提高 $0.33 \%$. 由此可见, Fe与Ti物种在ZSM-5沸石分子篎中的存在有利于提高轻烯烃的产率, 有望在石油炼制过程中提高烯烃产率.

关键词：天然凹凸棒石；铁; 钛；ZSM-5；沸石分子篮；催化裂化；丙烯 
收稿日期: 2012-12-30. 接受日期: 2013-04-28. 出版日期: 2013-08-20.

*通讯联系人. 电话: (0571)88273698; 电子信箱: fsxiao@zju.edu.cn

基金来源：国家自然科学基金(U1162201).

本文的英文电子版由Elsevier出版社在ScienceDirect上出版(http://www.sciencedirect.com/science/journal/18722067).

\section{1. 前言}

丙烯等轻烯烃是目前最重要的化工原料之一, 其需 求量正在逐年增加. 当前, 丙烯的生产主要有蒸汽裂解 和催化裂化(FCC)过程 ${ }^{[1-4]}$. 蒸汽裂解联产丙烯主要来自 石脑油的裂解, 但石脑油的供给量持续下降, 不能满足 丙烯日益增长的需求. 比较而言, FCC技术具有投资小、 丙烯/乙烯比值高、生产成本低等优点, 因而采用该工艺 生产丙烯的产量比例近年来逐年增加 ${ }^{[5,6]}$. ZSM-5沸石 分子篎因其独特的三维十元环的孔道结构、良好的热稳 定性和水热稳定性 ${ }^{[7]}$ 、以及低氢转移活性 ${ }^{[8,9]}$ 等特点而成 为最主要的FCC催化剂的添加剂, 对提高丙烯产率方面 起着极其重要的作用。

在制备FCC高效添加剂的过程中, 一个有效手段是 向ZSM-5沸石分子篮引入过渡金属 ${ }^{[10-14]}$. Lu等 ${ }^{[15,16]}$ 通过 在ZSM-5沸石上负载Fe和 $\mathrm{Cr}$, 提高了其催化裂化异丁烷 中的丙烯和乙烯的产率; Maia等 ${ }^{[17,18]}$ 采用浸渍和离子交 换法向ZSM-5中引入Ni元素, 提高了对轻烯烃的催化活 性和选择性; Shen等 ${ }^{[19,20]}$ 通过浸渍向ZSM-5沸石分子䇥 中引入 $\mathrm{Fe}$ 和Ti以增加丙烯和乙烯的产率. 由于含有过渡 金属的ZSM-5沸石的传统制备方法的步骤一般都较为 复杂, 且纯的化学试剂作为原料. 因此, 采用低成本的原 料, 通过一步法来合成掺有多种过渡金属的ZSM-5沸石 具有重要意义.

凹凸棒石(ATP)是一种含有 $\mathrm{Mg}, \mathrm{Al}, \mathrm{Fe}$ 和 $\mathrm{Ti}$ 等的天 然硅酸盐矿土, 具有独特的层链状结构、高的比表面积 和纳米纤维状的形貌 ${ }^{[21-26]}$, 因而广泛用作吸附剂、填充 剂和催化剂载体等 ${ }^{[27-31]}$. 通过一定的酸处理可以有效脱 除凹凸棒石中绝大多数的金属物种, 从而得到无定形的 硅源和少量的 $\mathrm{Al}, \mathrm{Fe}$ 和 $\mathrm{Ti}$ 物种, 这为一步法合成含有 $\mathrm{Fe}$ 和Ti过渡元素的ZSM-5沸石催化材料提供了很好的起始 原料.

本文以天然凹凸棒石为原料, 通过预处理得到含有 少量铁源和钛源的无定形硅源, 在加入有机模板剂和少 量铝源后, 一步合成含有 $\mathrm{Fe}$ 与 Ti物种的ZSM-5沸石材料 (Fe/Ti-ZSM-5)并用于(LGO，加拿大)的催化裂化反应中.

\section{2. 实验部分}

\subsection{Fe/Ti-ZSM-5样品的制备}

凹凸棒石购自江苏盯眙领域科技有限公司, 组成 $\mathrm{SiO}_{2} / \mathrm{MgO} / \mathrm{Al}_{2} \mathrm{O}_{3} / \mathrm{Fe}_{2} \mathrm{O}_{3} / \mathrm{CaO} / \mathrm{K}_{2} \mathrm{O} / \mathrm{Na}_{2} \mathrm{O} / \mathrm{TiO}_{2} / \mathrm{H}_{2} \mathrm{O}$ (wt\%) 为 59.83/14.49/8.35/4.20/0.79/0.77/0.22/1.10/10.15. 其它 试剂均来自上海化学试剂有限公司.

ATP 使用前, 用 $37 \% \mathrm{HCl}$ 处理．将 $2.7 \mathrm{~g}$ 的浓 $\mathrm{HCl}$ (37\%)加到 $17 \mathrm{ml}$ 水中, 再加入 $2.0 \mathrm{~g}$ 凹凸棒石, 搅匀后加入 水热晶化釜中, 在 $180^{\circ} \mathrm{C}$ 中保持 $14 \mathrm{~h}$, 然后通过抽滤, 洗 涤, 直至无氯离子存在, 样品在 $120^{\circ} \mathrm{C}$ 下干燥 $4 \mathrm{~h}$ 后, 即得 预处理后的ATP样品, 主要含有无定形氧化硅和 $\mathrm{Al}, \mathrm{Fe}$ 与 $\mathrm{Ti}$ 物种.

将 $0.09 \mathrm{~g}$ 的偏铝酸钠(AR)加入到 $15 \mathrm{ml}$ 水中, 搅拌均 匀后再加入 $4.5 \mathrm{~g}$ 四丙基氢氧化铵(TPAOH，19.6 wt\%), 继续摚拌 $30 \mathrm{~min}$, 再加入 $1.5 \mathrm{~g}$ 处理后的凹凸棒石, 摚拌4 $\mathrm{h}$ 后, 把初始凝胶转移到晶化釜中, 于 $180^{\circ} \mathrm{C}$ 晶化 $14 \mathrm{~h}$. 经抽滤、洗涤, $120^{\circ} \mathrm{C}$ 干燥 $4 \mathrm{~h}$ 后, 在 $550^{\circ} \mathrm{C}$ 煅烧 $4 \mathrm{~h}$ 以除去 模板剂即得Fe/Ti-ZSM-5样品.

用等量的硅胶替代凹凸棒石作为硅源, 同上法制得 最终得到的样品记为ZSM-5-C样品.

将 $1.0 \mathrm{~g} \mathrm{ZSM-5}$ 分子篮加入到 $50 \mathrm{ml} 1 \mathrm{~mol} / \mathrm{L}$ 的硝酸 铵溶液中, 于 $80^{\circ} \mathrm{C}$ 交换 $12 \mathrm{~h}$, 交换两次, 通过抽滤, 洗涤, 在 $120^{\circ} \mathrm{C}$ 干燥 $4 \mathrm{~h}, 500{ }^{\circ} \mathrm{C}$ 焙烧 $4 \mathrm{~h}$, 即可得H型ZSM-5.

\section{2. 沸石分子篮表征}

元素分析使用感应耦合等离子体 (ICP), 在 Perkin-Elmer 3300 DV仪上完成. 扫描电镜(SEM)使用 Hitachi SU-1510型. X射线衍射(XRD)表征采用Rigaku Ultimate VI X-ray $(40 \mathrm{kV}, 40 \mathrm{~mA}), \mathrm{Cu} K_{a}$ 射线. 在进行氨 气程序升温脱附 $\left(\mathrm{NH}_{3}-\mathrm{TPD}\right)$ 时, 称取 $100 \mathrm{mg}$ 样品置于反 应器内, 以高纯 $\mathrm{N}_{2}$ 在 $400-650^{\circ} \mathrm{C}$ 吹扫 $1 \mathrm{~h}$, 然后降至室温. 注入氨气, 封闭样品管, 饱和吸附 $1 \mathrm{~h}$, 在 $\mathrm{N}_{2}$ 中升至 100 ${ }^{\circ} \mathrm{C}$, 吹扫至基线平稳. 然后, 以 $10^{\circ} \mathrm{C} / \mathrm{min}$ 的速率升温至 $700^{\circ} \mathrm{C}$, 记录信号. $\mathrm{H}_{2}$ 程序升温还原(TPR)实验在美国热 电公司 TPDTO1100Series仪上进行, TCD检测耗氢量. $\mathrm{N}_{2}$ 等温吸附脱附测试采用Micromeritics ASAP 2010M分 析仪. 实验前, 样品在 $300^{\circ} \mathrm{C}$ 真空条件下预处理 $10 \mathrm{~h}$. 比 表面积, 孔体积根据t-plot计算. 固体样品紫外-可见漫反 射光谱(UV-Vis)在日本Shimadzu UV-3100型紫外可见 光谱仪上测得, 以 $\mathrm{BaSO}_{4}$ 为参比物. 


\subsection{LGO催化裂化测试}

制备LGO催化剂时, 将35\%的ZSM-5、50\%的高岭土 和15\%的矾土粘结剂, 充分混合, 经喷雾成型得到含有 ZSM-5的小球形添加剂. LGO催化剂中含 $10 \%$ 的添加剂 和 90\%的主催化剂(USY), 其中添加剂为ZSM-5-C或

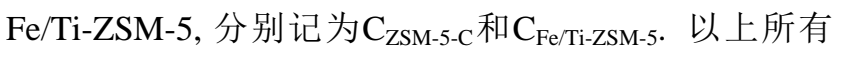
催化剂都在 $800{ }^{\circ} \mathrm{C}, 100 \%$ 水蒸气条件下处理 $4 \mathrm{~h}$, 以获得 稳定的反应活性, 再通过篮分法得到粒径在38-212 $\mu \mathrm{m}$ 大小的催化剂颗粒.

LGO催化裂化装置为ACE (Kayser Crop), 反应温度 为 $530{ }^{\circ} \mathrm{C}$, 催化剂和原料油的质量比为 6.0 , 接触时间 90 $\mathrm{s}$, 催化剂装载量为 $9 \mathrm{~g}$, 产物化学组成由GC-MS分析, 产 物分布的误差为 $0.01 \%$. 原料油来自加拿大, 具体性质 如表1所示.

\section{3. 结果与讨论}

\section{1. 凹凸棒石及Fe/Ti-ZSM-5表征结果}

图1为天然凹凸棒石在预处理前后的XRD谱. 由图 可见, 天然的凹凸棒石在 $8.35^{\circ}, 13.68^{\circ}, 16.31^{\circ}, 19.80^{\circ}$, $20.73^{\circ}, 21.34^{\circ}, 24.11^{\circ}, 27.47^{\circ}, 34.25^{\circ}$ 和 $35.24^{\circ}$ 等处出现 了明显的衍射峰, 表明此矿土具有良好的晶体结构. 经 过预处理后, 这些衍射峰基本上消失, 表明该样品基本 为无定形. 图2为凹凸棒石在预处理前后的SEM照片, 样 品在处理前后的形貌都是长度在 $1-2 \mu \mathrm{m}$, 直径为30-50 $\mathrm{nm}$ 的纤维状. 可见, 这种预处理对凹凸棒石形貌的影响 不大.

表2为凹凸棒石在预处理前后的元素组成. 可以看 出, 天然的凹凸棒石主要由 $\mathrm{SiO}_{2}$ (59.83\%)组成, 同时含 有大量的 $\mathrm{Mg}, \mathrm{Al}$ 和 $\mathrm{Fe}$, 少量的 $\mathrm{Na}, \mathrm{K}, \mathrm{Ca}, \mathrm{Mn}$ 和 Ti. 这些 金属离子一般都处于凹凸棒石层链状结构中的链与链 之间, 具有很高的稳定性, 只有通过高温炦烧或酸处理 使其失去层链状结构, 金属原子才有可能从凹凸棒石中 脱除. 由表可见, 凹凸棒石经过酸处理, 可以得到高含量 的 $\mathrm{SiO}_{2}(96.4 \%)$, 以及少量的 $\mathrm{Al}_{2} \mathrm{O}_{3}(0.8 \%) 、 \mathrm{Fe}_{2} \mathrm{O}_{3}(1.3 \%)$ 和 $\mathrm{TiO}_{2}$ (1.5\%). 可见, 酸处理可以破坏凹凸棒石的晶体结 构, 溶解八面体阳离子使凹凸棒失去层链状结构, 并脱 除其中的金属元素. 但是, 由于链状结构仍然存在, 因此 酸处理对凹凸棒石形貌的影响不大.

图3为Fe/Ti-ZSM-5在不同晶化时间下的XRD谱. 在 晶化之前, 凝胶呈现无定形状态; 当晶化 $2 \mathrm{~h}$, 样品出现 微弱的MFI结构的特征峰; 晶化 4-10 h, 样品在 23.03, $23.83^{\circ}$ 和 $24.28^{\circ}$ 处衍射峰快速增强, 说明晶体在此时间段
获得快速的生长; $12 \mathrm{~h}$ 后, 样品的衍射峰强度已无明显 变化, 说明体系的晶化过程已经结束, 最终得到结晶度 良好的ZSM-5沸石分子篮. 图 4 为不同晶化时间的 Fe/Ti-ZSM-5SEM照片. 由图可见, 在水热晶化之前, 样 品仍然保持凹凸棒石原有的纳米纤维状的形貌; 而 $2 \mathrm{~h}$ 以后, 产物中出现明显的颗粒状小晶体(0.5-1 $\mu \mathrm{m})$; 随着 晶化时间延长至6 $\mathrm{h}$, 小晶体逐渐变大 $(1.5-2.0 \mu \mathrm{m})$ 、变多; 继续延长晶化时间 $14 \mathrm{~h}$, 产物中纤维状的凹凸棒原料逐 渐减少, 直到消失, 而晶体颗粒大小绝大多数都分布在 $2.0 \mu \mathrm{m}$ 左右. 以上结果表明, 以凹凸棒石为原料, 合成 $\mathrm{Fe} / \mathrm{Ti}-\mathrm{ZSM}-5$ 的过程中, 由于使用了四丙基氢氧化铵作 为模板剂, 合成体系的诱导期很短 (2h); 初始凝胶中的 硅源仍然保持天然凹凸棒石的纳米级纤维状的形貌, 随 着晶化时间的延长, 纳米级纤维状硅源逐渐减少直至消 失. 还可以看出, ZSM-5-C样品晶粒比Fe/Ti-ZSM-5小.

表2为Fe/Ti-ZSM-5和ZSM-5-C的元素组成. 可以看 出, 二者的硅铝比(Si/Al)相近, 分别为14.4和13.2. 图5为 $\mathrm{Fe} / \mathrm{Ti}-\mathrm{ZSM}-5$ 和ZSM-5-C的 $\mathrm{N}_{2}$ 吸附等温线. 由图可见, 二 样品的等温线均为典型的 I 型微孔等温线, 说明样品具 有特征的微孔孔道结构. 表 3给出了 Fe/Ti-ZSM-5 和 ZSM-5-C的比表面积、微孔比表面、外比表面积、总孔 体积和微孔孔体积. 可以看出, 样品的比表面积和孔体 积十分接近. 由此可见, 以凹凸棒石为原料, 采用一步法 可成功合成出Fe/Ti-ZSM-5沸石分子篮, 其硅铝比, 表面 积和孔体积与使用硅胶作为硅源合成的ZSM-5沸石分 子篮十分接近, 但引入了少量的 $\mathrm{Fe}$ 和 Ti 物种.

尽管由多种矿物可合成不同的沸石 ${ }^{[32-34]}$, 以凹凸棒 为原料也可低硅的 $\mathrm{A}$ 沸石 ${ }^{[35]}$, 但高硅沸石尚未见报道. 因此, 本文由凹凸棒一步法合成Fe/Ti-ZSM-5沸石分子 笁对于工业应用具有潜在的重要意义.

为研究金属原子在样品中的配位状况, 图6给出了 天然凹凸棒石、预处理后的凹凸棒石以及合成的 $\mathrm{Fe} / \mathrm{Ti}-Z S M-5$ 的UV-Vis谱. 可以看出, 天然的凹凸棒石在 $250 \mathrm{~nm}$ 处有一吸收峰, 这可能由于多种金属 $(\mathrm{Mg}, \mathrm{Al}, \mathrm{Fe}$, $\mathrm{Mn}, \mathrm{Ti})$ 的相互干扰叠加形成的. 经酸处理后, 在 200-400 nm附近出现了非常宽的吸收峰, 这与Fe, Ti两 种金属有关系. 而在Fe/Ti-ZSM-5样品上于 212 和 $240 \mathrm{~nm}$ 两处出现吸收峰, 这是典型的MFI沸石分子篮骨架上 $\mathrm{Ti}^{4+}$ 和 $\mathrm{Fe}^{4+}$ 的电子跃迁信号, 一般认为 $212 \mathrm{~nm}$ 处的吸收峰 归属为晶体中四配位钛的电荷转移跃迁, $240 \mathrm{~nm}$ 处的吸 收峰归属为晶体中的四配位的铁的电荷转移跃迁. 另 外, 该样品还在 $325 \mathrm{~nm}$ 附近出现小峰, 这可能与典型的 
体相 $\mathrm{TiO}_{2}$ 的吸收峰有关. 由此可见, 在使用凹凸棒石为 原料合成的 Fe/Ti-ZSM-5的过程中, 原料中的Fe和 Ti物种 部分进入ZSM-5沸石分子篮的骨架结构中以四配位的 形式存在, 同时也有部分以氧化物形态存在于沸石分子 篮的骨架之外.

图7为 Fe/Ti-ZSM-5和ZSM-5-C的 $\mathrm{NH}_{3}$-TPD谱.一般 认为, 脱附温度低于 $200,200-400$ 以及高于 $400^{\circ} \mathrm{C}$ 的脱 附峰分别对应于弱、中强和强酸性的酸中心, 而脱附峰 的积分面积大小代表材料酸量 ${ }^{[36]}$. 由图7可见, 两样品 都在 218 和 $440^{\circ} \mathrm{C}$ 附近出现脱附峰, 但是由于 $\mathrm{Fe}$ 与 $\mathrm{Ti}$ 物种 的存在对 $\mathrm{Al}$ 原子进入到ZSM-5结构中略有影响, 使得 Fe/Ti-ZSM-5在硅铝比值比ZSM-5-C的略大, 从而导致 $\mathrm{Fe} / \mathrm{Ti}-\mathrm{ZSM}-5$ 酸量略小.

图8为Fe/Ti-ZSM-5和ZSM-5-C样品的 $\mathrm{H}_{2}$-TPR谱. 一 般认为, 单一的 $\mathrm{Fe}$ 原子负载在ZSM-5沸石分子篮上时, 于 350 和 $420^{\circ} \mathrm{C}$ 出现还原峰, 对应于 $\mathrm{Fe}^{3+}$ 被还原为 $\mathrm{Fe}^{2+}$ 进 一步还原为 $\mathrm{Fe}$; 当仅 $\mathrm{Ti}$ 负载在 $\mathrm{ZSM}-5$ 时, 其在 $670^{\circ} \mathrm{C}$ 出 现还原峰, 对应于 $\mathrm{TiO}_{2}$ 的还原 ${ }^{[19,20]}$. 可以看出, ZSM-5-C 没有还原峰出现, 因为此样品中无任何可被还原的金属 离子; 但Fe/Ti-ZSM-5 在 $400-700{ }^{\circ} \mathrm{C}$ 范围内却有明显的 还原峰, 其还原温度显然不同于单一的 $\mathrm{Fe}$ 物种或 $\mathrm{Ti}$ 物 种 ${ }^{[19,20]}$, 这可能是由于骨架中Fe物种较难还原, 出峰温 度升高, 而处于骨架之外的 $\mathrm{TiO}_{2}$ 与沸石分子篮表面羟基
的相互作用下被 $\mathrm{H}_{2}$ 还原, 故出峰温度下降.

\subsection{Fe/Ti-ZSM-5分子笁的催化性能}

表4为含 Fe/Ti-ZSM-5和ZSM-5-C的催化剂样品上的 LGO催化裂化反应结果. 由表可见, 以ZSM-5-C作为添 加剂时, 丙烯和总轻烯烃的产率是 $5.98 \%$ 和 $12.66 \%$, 而采 用 Fe/Ti-ZSM-5作为添加剂时, 丙烯和总轻烯烃的产率 分别为 $6.16 \%$ 和 $12.99 \%$, 分别提高了 $0.18 \%$ 和 $0.33 \%$. 比 较而言, ZSM-5-C的晶体尺寸更小, 外比表面积大, 硅铝 比较低, 酸量略大, 但是Fe/Ti-ZSM-5对轻烯烃具有更好 的选择性和活性. 这显然与样品中含有铁和钛物种有 关. 这可能是由于 $\mathrm{Ti}$ 和 $\mathrm{Fe}$ 物种加入到分子篮中, 可以有 效地提高催化剂的氧化还原性能, 有利于饱和烷烃氧化 脱氢到不饱和烯烃, 再经过 $\beta$-断裂后, 就可以产生更多 的低碳烯烃, 从而提高轻烯烃的产率, 与最近文献一 致 ${ }^{[11,18-20]}$.

\section{4. 结论}

以凹凸棒石为原料一步法成功合成出Fe/Ti-ZSM-5 沸石分子篮, 该样品具有与常规的ZSM-5相类似的结晶 度、比表面积和孔体积和酸性, 但在催化裂化LGO反应 中, 表现出比常规ZSM-5更高的丙烯的选择性和总的轻 烯烃产率, 这与它的独特氧化还原性能有关. 本结果对 FCC法多产丙烯和提高轻烯烃产率有潜在的应用意义. 